Agnieszka Grzelak

Szkoła Główna Handlowa,

Biuro Analiz Sejmowych

\title{
PRZEDAWNIENIE KARALNOŚCI PRZESTĘPSTW SEKSUALNYCH W KONTEKŚCIE PRAWA UNII EUROPEJSKIEJ
}

\section{Wprowadzenie}

W ostatnim okresie do Marszałka Sejmu wpłynęło kilka projektów ustaw, które dotyczyły problemu przedawnienia przestępstw o charakterze seksualnym ${ }^{1}$, głównie w odniesieniu do jego terminu. Przedłożone projekty, zawierające propozycje zmian w art. $101 \S 4$ ustawy z dnia 6 czerwca 1997 r. - Kodeks karny² (dalej jako: k.k.) lub w art. 105 k.k., zostały wniesione zarówno przez grupy posłów, jak i przez rząd. Ostatecznie 21 lutego 2014 r. przyjęto zmiany w art. $101 \S 4$ k.k. będące efektem prac nad projektem rządowym ${ }^{3}$. Ponieważ problematyka walki z tego typu przestępczością jest przedmiotem prawa Unii Europejskiej, o czym będzie mowa w dalszej części artykułu, można rozważyć, czy i w jakim zakresie proponowane zmiany, odnoszące się do terminu przedawnienia, są zgodne z przepisami prawa wtórnego UE oraz czy ewentualnie mogą zostać uznane za zmiany, które implementują do prawa polskiego obowiązki nałożone przepisami UE - a zatem, czy dotychczas obowiązujący art. $101 \S 4$ k.k. nie był zgodny z prawem europejskim. Analiza tego przykładu może być przyczynkiem do dalszej dyskusji nad określeniem zakresu harmonizacji krajowego prawa karnego i zobowiązań państw w dziedzinie prawa karnego materialnego.

Artykuł $101 \S 4$ k.k. w stanie prawnym przed uchwaleniem ww. ustawy ${ }^{4}$ stanowi: Przedawnienie karalności przestępstw określonych $w$ art. 199 \& 2 3, art. 200, art. $202 \S 2$ i 4 oraz art. 204 3, jak również przestępstw określonych wart. 197, art.

Zob. druki sejmowe - VII kadencja - nr 1827, 1878, 2024 i 2016.

Dz.U. z 1997 r. Nr 88, poz. 553 ze zm.

W dniu 24 lutego 2014 r. projekt został przekazany do podpisu Prezydenta i jeszcze nie jest opublikowany w Dzienniku Ustaw. Zob. http://www.sejm.gov.pl/Sejm7.nsf/PrzebiegProc.xsp?nr=2016 (dostęp 28 lutego 2014 r.) Stan prawny na dzień 28 lutego 2014 r. 
201, art. $202 \S 3$, art. 203 i art. $204 \S 4$, w przypadku gdy pokrzywdzonym jest matoletni-nie może nastapić przed uptywem 5 lat od ukończenia przez pokrzywdzonego 18 lat. Przepis ten został wprowadzony do k.k. ustawą z dnia 24 października 2008 r. o zmianie ustawy - Kodeks karny oraz niektórych innych ustaw ${ }^{6}$. Ratio legis tego przepisu było umożliwienie, by osoba pokrzywdzona w dzieciństwie przestępstwem seksualnym po uzyskaniu pełnoletności, czyli już w pełni świadomie i niezależnie od możliwej presji ze strony sprawcy, mogła ujawnić popełnienie tego przestępstwa. Wprowadzenie do k.k. tego rozwiązania wynikało również z konieczności dostosowania prawa polskiego do przepisów decyzji ramowej Rady 2004/68/WSiSW z 22 grudnia 2003 r. o zwalczaniu seksualnego wykorzystywania dzieci i pornografii dziecięcej ${ }^{7}$. Akt ten w art. 8 ust. 6 zobowiązał państwa członkowskie do umożliwienia ścigania przynajmniej najpoważniejszych przestępstw w nim określonych ${ }^{8}$ po uzyskaniu przez pokrzywdzone dziecko pełnoletniości. Do tego czasu w prawie polskim nie było zatem żadnych szczególnych przepisów dotyczących przedawnienia przestępstw o charakterze seksualnym.

Przedstawiając zatem teraz przedłożone projekty zmian, których efektem jest uchwalona ustawa, należy podkreślić, że wszystkie one dotyczyły kwestii terminu przedawnienia przestępstw $\mathrm{w}$ nim wymienionych i na to zagadnienie położony zostanie nacisk w dalszej części opracowania. Poza rozważaniami pozostaną te zmiany, które dotyczą zakresu przedmiotowego, bowiem wydają się one zbyt kazuistyczne do omówienia w niniejszym artykule. W związku z tym, w artykule będzie mowa ogólnie o ,przestępstwach o charakterze seksualnym” lub ,przestępstwach seksualnych" w rozumieniu tych, których dotyczy art. $101 \S 4$ k.k., zarówno w wersji obowiązującej, jak i w przedłożonych projektach. Nie jest przedmiotem analizy zakres przedmiotowy tego pojęcia - wymagałoby to zupełnie odrębnego artykułu.

Rozpoczynając od pierwszego przedłożonego projektu (druk $\mathrm{nr}$ 1827), należy zauważyć, że zaproponowano w nim zmianę art. $101 \S 4$ k.k. polegającą na tym, że przedawnienie karalności czynów zabronionych wymienionych $w$ tym przepisie nie może nastąpić przed upływem 10 lat od ukończenia przez pokrzywdzonego 18 lat.

Należy zauważyć, że ustawą z dnia 20 maja 2010 r. o zmianie ustawy - Kodeks karny, ustawy o Policji, ustawy - Przepisy wprowadzające Kodeks karny oraz ustawy - Kodeks postępowania karnego (Dz.U. Nr 98, poz. 626) uchylony został art. 204 § 4, w którym stypizowane zostało przestępstwo polegające na zwabieniu lub uprowadzeniu innej osoby, w celu uprawiania prostytucji za granicą. Uchylenie art. $204 \S 4$ k.k. stanowiło konsekwencję wprowadzenia do Kodeksu karnego definicji handlu ludźmi (art. $115 \S 22$ k.k.) i penalizacji w art. 189a k.k. czynu polegającego na handlu ludźmi.

6 Dz.U. Nr 214, poz. 1344.

$7 \quad$ Dz.U. UE L 013 z 20.01.2004 r., s. 44

8 Chodziło o wymienione w art. 2 decyzji ramowej przestępstwa związane z seksualnym wykorzystaniem dzieci. Przepis ten stanowił, że każde państwo członkowskie podejmie niezbędne środki w celu zapewnienia poddania karze następujących czynów popełnionych umyślnie: a) zmuszanie dziecka do prostytucji lub udziału w przedstawieniach pornograficznych, lub czerpanie z tego zysku, albo wykorzystywanie dziecka w inny sposób do takich celów; b) nakłanianie dziecka do prostytucji lub udziału w przedstawieniach pornograficznych; c) uczestnictwo w czynnościach o charakterze seksualnym z udziałem dziecka: i) z użyciem przymusu, siły lub groźby; ii) w zamian za pieniądze lub inne wynagrodzenie jako opłatę za udział dziecka w czynnościach o charakterze seksualnym; iii) poprzez wykorzystanie stosunku zaufania, władzy lub wpływu na dziecko. 
Zmiana zaproponowana w projekcie ustawy, zawartym w druku sejmowym nr 1878, przewiduje nowelizację art. $101 \S 4$ k.k. m.in. w ten sposób, że przedawnienie karalności czynów zabronionych wymienionych w tym przepisie nie mogłoby nastąpić przed upływem 12 lat od ukończenia przez pokrzywdzonego 18 lat.

Uzasadnienia do tych dwóch projektów poselskich są niemal identyczne w tym sensie, że wskazuje się w nich na potrzebę zapewnienia realnej możliwości pociągnięcia do odpowiedzialności karnej sprawców przestępstw o charakterze seksualnym popełnionych na szkodę małoletnich. W opinii projektodawców dotychczasowe regulacje nie spełniały tego celu, gdyż często w okresie 5 lat od osiągnięcia pełnoletniości (a zatem w obecnie obowiązującym okresie przedawnienia) pokrzywdzony pozostawał w stosunku faktycznej zależności emocjonalnej lub finansowej od sprawcy. Dodatkowo, we wskazanym okresie mogło dojść do prawomocnego zakończenia postępowania karnego wobec sprawcy. W wieku 23 lat wiele osób jest niesamodzielnych i niedojrzałych, a ponadto - zdaniem wnioskodawców - bardzo silna jest obawa przed ujawnieniem faktu, że stały się ofiarami przemocy seksualnej. Niejednokrotnie pokrzywdzony mieszka jeszcze ze sprawcą, jest od niego uzależniony materialnie i psychicznie. Przestępstwa te zatem często nie są ujawniane ze względu na wiek pokrzywdzonego - jego obawę przed ujawnieniem się, niejednokrotnie spowodowaną agresywnym zachowaniem sprawcy. W praktyce oznacza to niemożność przeciwstawienia się sprawcy i ochrony własnych, podstawowych praw. Obowiązkiem ustawodawcy jest zapewnienie realnej możliwości pociągnięcia sprawcy do odpowiedzialności karnej. Strach pokrzywdzonego nie może stanowić okoliczności wpływającej na uniknięcie odpowiedzialności karnej przez sprawcę.

Projekty miały więc na celu - zdaniem wnioskodawców - ochronę praworządności oraz interesów ofiar przestępstw na tle seksualnym poprzez wydłużenie okresu przedawnienia karalności. Racjonalną granicą jest - zdaniem Autorów projektu z druku 1827 - okres 10 lat. Autorzy projektu z druku 1878 uznają, że granicą powinno być osiągnięcie przez pokrzywdzonego 30. roku życia. Wskazują przy tym, że właśnie okres 30 lat jest najdłuższym znanym polskiemu prawu okresem przedawnienia - oczywiście pomijając czyny, które przedawnieniu nie ulegają.

Podobną propozycję zawarto w projekcie rządowym, zawartym w druku nr 2016. Rządowy projekt ustawy o zmianie ustawy - Kodeks karny oraz niektórych innych ustaw, mający na celu implementację do prawa polskiego dyrektywy 2011/93/ UE, został przekazany do Sejmu 17 grudnia 2013 r. (druk nr 2016) ${ }^{9}$. Projekt ustawy miał na celu doprowadzenie do zgodności polskich regulacji karnoprawnych z postanowieniami Konwencji Rady Europy o ochronie dzieci przed seksualnym wykorzystywaniem i niegodziwym traktowaniem w celach seksualnych (dalej jako: Konwencja z Lanzaroty) oraz, w zakresie dotyczącym zwalczania przestępstw związanych z pornografią dziecięcą, Konwencji Rady Europy o cyberprzestępczości. 
Projekt rządowy zawierał zatem przepisy uzupełniające zmiany, które weszły w życie 27 stycznia 2014 r., a które wynikały z przyjętej w wyniku przedłożeń poselskich ustawy z dnia 13 czerwca 2013 r. o zmianie ustawy - Kodeks karny oraz ustawy - Kodeks postępowania karnego (Dz.U. z 2013 r., poz. 849), dotyczące pozycji procesowej małoletnich pokrzywdzonych przestępstwami o charakterze seksualnym.

Rząd zaproponował, by w przypadku gdy pokrzywdzonym jest małoletni albo gdy treści pornograficzne, o których mowa w art. 202 k.k., obejmują udział małoletniego, przedawnienie karalności przestępstwa określonego w rozdziale XXV nie może nastąpić przed upływem 10 lat od ukończenia przez tego małoletniego 18 lat. Uzasadnieniem dla tej zmiany miało być przede wszystkim dostosowanie do prawa UE. Należy jednak dodać, że w ostatecznie uchwalonej wersji ustawy przyjęto, że w przypadku gdy pokrzywdzonym jest małoletni, przedawnienie karalności przestępstw określonych w art. 189a § 1 k.k. oraz w rozdziale XXV nie może nastąpić przed ukończeniem przez tego pokrzywdzonego 30. roku życia, a zatem okres ten został - w stosunku do projektu - wydłużony o 2 lata.

Wreszcie, w najdalej idącym projekcie poselskim, zawartym w druku sejmowym $\mathrm{nr} 2024$, zaproponowano zmianę art. 105 k.k. polegającą na dodaniu w tym artykule $\S 3$, zgodnie z którym do czynów określonych w art. 197, art. 200, art. 200a oraz art. 201 k.k. nie miałyby mieć zastosowania zasady odnoszące się do przedawnienia karalności przestępstwa, wynikające z art. 101-103 k.k. W konsekwencji czyny te miałyby w ogóle nie podlegać przedawnieniu. Propozycja nieprzedawniania się wymienionych przestępstw była reakcją - jak piszą wnioskodawcy w uzasadnieniu - na pojawiające się problemy ofiar w uzyskaniu możliwości wejścia na drogę sprawiedliwości wobec swoich oprawców. Ważnym tutaj jest wzięcie pod uwagę faktu, dotyczącego sfery psychicznej ofiar w związku z popełnieniem przestępstw seksualnych. Wnioskodawcy napisali, że pokrzywdzeni „,zapominają o swoich krzywdach na długie lata. Zdarza się, że ofiary dopiero po długim okresie mogą dopuścić do swojej świadomości krzywdy, jakie je spotkały w przeszłości i dopiero wtedy są gotowe na dochodzenie swoich praw przed niezawisłym sądem (...). Rezygnacja $\mathrm{z}$ instytucji przedawnienia $\mathrm{w}$ tym przypadku będzie dodatkową ochroną ofiary. W efekcie, karalność przestępstw na tle seksualnym, jak i możliwość wykonania orzeczonej kary względem oskarżonych za te przestępstwa nie powinna i nie może podlegać instytucji przedawnienia, dając tym samym prawo do łaski pedofilom i gwałcicielom". Wnioskodawcy piszą, że ustawodawca ma obowiązek zapewnić możliwość prawną pociągnięcia sprawców tych przestępstw (czynów) do odpowiedzialności karnej w każdym możliwym czasie, z uwzględnieniem stanu ich ofiar i ich gotowości do podjęcia określonych kroków prawnych w dążeniu do prawdy, w poszanowaniu prawa i jego gwarancji społecznych względem pokrzywdzonych. Ustawodawca zobowiązany jest do takiej konstrukcji przepisów prawnych, aby termin przedawnienia dla wszczęcia postępowania w związku z przestępstwami o charakterze seksualnym biegł w czasie wystarczającym do skutecznego wszczęcia postępo- 
wania po uzyskaniu przez pokrzywdzonego możliwości dochodzenia swoich praw przed wymiarem sprawiedliwości. Z uwagi na charakter tych przestępstw, ich indywidualność, emocjonalność oraz możliwość przez pokrzywdzonego dochodzenia swoich praw, właściwym - zdaniem twórców projektu ustawy z druku 2024 - byłoby zakwalifikowanie przez ustawodawcę tych czynów zabronionych do katalogu przestępstw z art. 105 k.k., a więc przestępstw niepodlegających przedawnieniu.

\section{Przepisy prawa UE i prawa międzynarodowego dotyczące seksualnego wykorzystywania dzieci}

Bez wątpienia, wykorzystanie seksualne dzieci w jakiejkolwiek formie stanowi poważne pogwałcenie praw podstawowych, w szczególności praw dzieci do ochrony i opieki niezbędnych dla ich dobra. Prawa te - na poziomie umów międzynarodowych - określone są w szczególności w Konwencji ONZ o prawach dziecka z 1989 r., Konwencji Rady Europy o ochronie dzieci przed seksualnym wykorzystaniem i niegodziwym traktowaniem w celach seksualnych z 2007 r. (Konwencja z Lanzarote) ${ }^{10}$ oraz w Karcie praw podstawowych UE (KPP).

Zgodnie z art. 34 Konwencji ONZ, państwa będące stronami zobowiązują się chronić dzieci przed wszelkimi formami wykorzystywania seksualnego i niegodziwego traktowania w celach seksualnych. Podobnie, Konwencja z Lanzarote jest aktem pogłębiającym współpracę państw w tej dziedzinie. Z kolei w art. 24 ust. 2 KPP stanowi się, że we wszystkich działaniach dotyczących dzieci, podejmowanych zarówno przez władze publiczne, jak i instytucje prywatne, należy uwzględniać przede wszystkim dobro dziecka.

Wyrazem działań podejmowanych w celu walki z omawianym zjawiskiem są również postanowienia zawarte $\mathrm{w}$ rozmaitych programach o charakterze politycznym. W szczególności, „Program sztokholmski - otwarta i bezpieczna Europa dla dobra i ochrony obywateli" ${ }^{11}$ w sposób wyraźny przyznaje priorytet walce z niegodziwym traktowaniem dzieci.

Przestępczością na tle seksualnym zajęto się również na poziomie prawa wtórnego UE - przyjmowane akty prawne UE odnoszą się do tych zagadnień wprost, nakazując państwom członkowskim podejmowanie stosownych działań i przyjmowanie przepisów realizujących ich założenia. Do czasu wejścia w życie Traktatu z Lizbony w szczególności decyzja ramowa Rady 2004/68/WSiSW z 22 grudnia 2003 r. dotycząca zwalczania seksualnego wykorzystywania dzieci i pornografii dziecięcej ${ }^{12}$ zakładała zbliżenie ustawodawstwa państw członkowskich w zakresie

\footnotetext{
10 Konwencja została podpisana przez Polskę w 2007 r., ale jeszcze nie jest ratyfikowana. Na temat przyczyn opóźnienia w ratyfikacji zob. odpowiedź z 26 września 2013 r. Podsekretarza Stanu w Ministerstwie Sprawiedliwości na interpelację poselską nr 20673.

11 Dz.U. UE C 115, 4.5.2010, s. 1.

12 Dz.U. UE L 13 z 20.1.2004 r., s. 44.
} 
penalizacji najgroźniejszych form przestępstw, rozszerzenia jurysdykcji krajowej oraz zapewnienia ofiarom minimalnego wspólnego poziomu ochrony. Również decyzja ramowa 2001/22/WSiSW z 15 marca 2001 r. w sprawie pozycji ofiar w postępowaniu karnym ${ }^{13}$ ustanawiała pakiet praw przysługujących pokrzywdzonym w postępowaniu karnym, w tym prawo do ochrony i odszkodowania. Z kolei koordynacja ścigania przypadków niegodziwego traktowania dzieci w celach seksualnych i ich wykorzystywania była przedmiotem decyzji ramowej 2009/948/WSiSW z 30 listopada 2009 r. w sprawie zapobiegania konfliktom jurysdykcji w postępowaniu karnym i w sprawie rozstrzygania takich konfliktów ${ }^{14}$.

Po wejściu w życie Traktatu z Lizbony możliwe stało się przyjęcie dalej idących aktów prawnych UE, w związku ze zmianami systemowymi, jakie dotyczyły obszaru współpracy organów wymiaru sprawiedliwości w sprawach karnych w UE ${ }^{15}$. W efekcie, w dość krótkim czasie, bowiem już 13 grudnia 2011 r., przyjęto dyrektywę Parlamentu Europejskiego i Rady 2011/93/UE (dalej jako: dyrektywa) ${ }^{16}$. Zgodnie z jej preambułą, jej postanowienia uzupełniają się z dyrektywą 2011/36/ UE z 5 kwietnia 2011 r. w sprawie zapobiegania handlowi ludźmi i zwalczania tego procederu oraz ochrony ofiar ${ }^{17}$. W ostatnim czasie przyjęto również dyrektywę Parlamentu Europejskiego i Rady 2012/29/UE z dnia 25 października 2012 r. ustanawiającą normy minimalne $\mathrm{w}$ zakresie praw, wsparcia $\mathrm{i}$ ochrony ofiar przestępstw oraz zastępującą decyzję ramową Rady 2001/220/WSiSW ${ }^{18}$.

Celem ogólnym dyrektywy 2011/93/UE, która będzie podstawowym aktem przedstawionym dalej, zgodnie z tytułem, jest zwalczanie niegodziwego traktowania w celach seksualnych i wykorzystywania seksualnego dzieci oraz pornografii dziecięcej $^{19}$. Dyrektywa ustanawia minimalne normy dotyczące określania przestępstw i kar dotyczących niegodziwego traktowania w celach seksualnych i wykorzystywania seksualnego dzieci, pornografii dziecięcej oraz nagabywania dzieci dla celów seksualnych. Wprowadza również przepisy służące lepszemu zapobieganiu takim przestępstwom i lepszej ochronie pokrzywdzonych w wyniku takich przestępstw.

13

Dz.U. UE L 82, 22.3.2001 r., s. 1.

Dz.U. UE L 328, 15.12.2009 r., s. 42.

Por. A. Grzelak, Komentarz do art. 67 i n. Traktatu o funkcjonowaniu Unii Europejskiej, (w:) A. Wróbel, D. Miąsik, N. Półtorak (red.), Traktat o funkcjonowaniu Unii Europejskiej. Komentarz, Warszawa 2012, s. 1021 i n.

Zob. dyrektywę Parlamentu Europejskiego i Rady 2011/93/UE z dnia 13 grudnia 2011 r. w sprawie zwalczania niegodziwego traktowania w celach seksualnych i wykorzystywania seksualnego dzieci oraz pornografii dziecięcej, zastępującą decyzję ramową Rady 2004/68/WSiSW; Dz.U. UE L 335 z 17.12.2011 r., s. 1, ze sprostowaniem dotyczącym numeru dyrektywy, opublikowanym w Dz.U. UE L 18 z 21.1.2012 r., s. 7.

Dz.U. L 101, 15.4.2011 r., s. 1.

Dz.U. L 315, 14.11.2012 r., s. 57

Szerzej na temat tej dyrektywy zob. B. Weißer, Angleichung von Strafvorschriften zur grenzüberschreitenden (organisierten) Kriminalität, (w:) M. Böse (red.), Europäisches Strafrecht mit polizeilicher Zusammenarbeit, Nomos Baden-Baden 2013, § 9, RN 64 i n., s. 364 i n. Zob. także M. Skórzewska-Amberg, Zwalczanie niegodziwego traktowania w celach seksualnych i wykorzystywania seksualnego dzieci oraz pornografii dziecięcej (na tle dyrektywy 2011/92/UE), „Państwo i Prawo” 2013, nr 8, s. 52. Warto zwrócić uwagę, że Autorka tego ostatniego tekstu nie uwzględniła zmiany numeru dyrektywy. Por. ww. sprostowanie. 
Dyrektywa uchyla i zastępuje decyzję ramową Rady 2004/68/WSiSW. Termin implementacji przepisów tej dyrektywy upłynął 18 grudnia 2013 r. $^{20}$

Dyrektywa zawiera podstawowe definicje. W szczególności, pod pojęciem „dziecko" rozumie się każdą osobę w wieku poniżej 18 lat. W kolejnych przepisach (art. 3-6) wymieniono czyny, w stosunku do których państwa członkowskie zobowiązane są podjąć środki niezbędne do ich karalności, związane z:

- niegodziwym traktowaniem w celach seksualnych,

- wykorzystywaniem seksualnym,

- pornografią dziecięcą,

- nagabywaniem dzieci do celów seksualnych.

Ponadto, dyrektywa określa, w przypadku których z tych czynów karalne powinno być również przynajmniej podżeganie, pomocnictwo czy usiłowanie ich popełnienia. W kolejnych przepisach dyrektywa odnosi się do kwestii pozbawienia praw na podstawie wyroku skazującego (art. 10), w zakresie nakładania zakazu wykonywania zawodowej działalności związanej z bezpośrednimi i regularnymi kontaktami z dziećmi.

Dyrektywa reguluje także podstawowe zasady związane z postępowaniem karnym w sprawach dotyczących przestępstw w niej określonych. W szczególności, zobowiązuje państwa członkowskie do podjęcia środków niezbędnych do zapewnienia, by ściganie i oskarżenie nie było uzależnione od złożenia przez pokrzywdzonego lub przez jego przedstawiciela skargi lub oskarżenia, oraz by mogło być kontynuowane nawet, gdy ta osoba wycofa swoje zeznania (art. 15 ust. 1). Ponadto, zobowiązuje się państwa, by wymienione w art. 15 ust. 2 czyny mogły być ścigane przez wystarczający i proporcjonalny do wagi danego przestępstwa okres od momentu osiągnięcia pełnoletniości przez pokrzywdzonego.

Kolejne przepisy dotyczą jurysdykcji i koordynowania ścigania, pomocy i wsparcia dla pokrzywdzonych dzieci oraz ich ochrony, środków zapobiegających reklamowaniu okazji do niegodziwego traktowania i turystyki seksualnej oraz ogólnie ujmując - działań prewencyjnych, do których podjęcia zobowiązane są państwa członkowskie.

Zwrócić jeszcze należy uwagę na problematykę ochrony pokrzywdzonych dzieci podczas postępowania przygotowawczego i sądowego, w szczególności zobowiązania państw do podjęcia środków zmierzających do zapewnienia dzieciom dostępu do doradztwa prawnego i zastępstwa prawnego, a także do podjęcia określonych działań związanych z przesłuchaniami i rozprawą, w tym do przesłuchania dzieci bez nieuzasadnionej zwłoki, w pomieszczeniach specjalnie zaprojektowaKodeks karny oraz ustawy - Kodeks postępowania karnego, Dz.U. z 2013 r., poz. 849. Artykuł $101 \S 4$ k.k. nie był jednak przedmiotem zmian w tej ustawie. 
nych lub przystosowanych do tych celów, przez specjalistów odpowiednio przeszkolonych do tego celu lub z ich udziałem czy ich ograniczonej liczby. W art. 20 dyrektywy nakłada się na państwa członkowskie zobowiązanie, by liczba przesłuchań była jak najbardziej ograniczona i by były one przeprowadzane tylko w tych przypadkach, gdy jest to absolutnie niezbędne do celów postępowania (art. 20 ust. 3 lit. e dyrektywy) oraz by pokrzywdzonemu dziecku mógł towarzyszyć jego przedstawiciel prawny lub, w odpowiednich przypadkach, wybrana przez nie osoba dorosła, o ile nie podjęto odmiennej umotywowanej decyzji w odniesieniu do tej osoby (art. 20 ust. 3 lit. f dyrektywy). Państwa zobowiązane są również, by w trakcie postępowań karnych dotyczących przestępstw określonych w dyrektywie, wszystkie przesłuchania pokrzywdzonego dziecka lub dziecka występującego w roli świadka mogły być rejestrowane audiowizualnie i by te zarejestrowane przesłuchania mogły być wykorzystane jako dowód w postępowaniu sądowym przed sądem karnym (zob. art. 20 dyrektywy).

W odniesieniu zatem do omawianego $\mathrm{w}$ tym opracowaniu problemu przedawnienia dyrektywa wskazuje wyraźnie, że czyny muszą być ścigane przez wystarczający i proporcjonalny do wagi przestępstwa okres. Warto dodać, że nieobowiązująca jeszcze w Polsce Konwencja z Lanzarote w art. 33 nie nakłada na państwa obowiązku przyjęcia koniecznych środków w celu zapewnienia, aby termin przedawnienia dla wszczęcia postępowania $\mathrm{w}$ związku $\mathrm{z}$ wymienionymi przestępstwami biegł przez „wystarczający i współmierny do ciężaru przestępstwa okres od momentu osiągnięcia przez pokrzywdzonego pełnoletności”. Konwencja z Lanzarote również nie wskazuje okresów przedawnienia, pozostawiając ich doprecyzowanie ustawodawstwom krajowym.

Jak wspomniano wyżej, kwestia praw ofiar przestępstw jest przedmiotem regulacji dyrektywy 2012/29/UE z 25 października 2012 r. ustanawiającego normy minimalne w zakresie praw, wsparcia i ochrony ofiar przestępstw oraz zastępującej decyzję ramową Rady 2001/220/WSiSW ${ }^{21}$. Dyrektywa 2012/29/UE ma na celu zapewnienie, by ofiary przestępstwa otrzymały odpowiednie informacje, wsparcie i ochronę oraz by mogły uczestniczyć w postępowaniu karnym. Wskazana dyrektywa dotyczy ofiar przestępstw, zdefiniowanych w art. 2 ust. 1 lit. a dyrektywy, a zatem nie tylko dzieci, ale zgodnie z art. 1 ust. 2 dyrektywy, państwa członkowskie mają obowiązek zapewnić, by w przypadkach, gdy ofiarą jest dziecko, w pierwszym rzędzie brano pod uwagę najlepsze zabezpieczenie jego interesu, który należy ocenić indywidualnie dla każdego przypadku. Pierwszeństwo ma podejście dostosowane do dziecka, uwzględniające jego wiek, poziom dojrzałości, jego opinie, potrzeby i obawy. Również ta dyrektywa definiuje dziecko jako każdą osobę w wieku poniżej 18 lat. 


\section{Instytucja przedawnienia karalności}

Przedawnienie karalności jest instytucją prawa karnego, opierającą się na przekonaniu, że po upływie znacznego czasu od popełnienia przestępstwa pociąganie jego sprawcy do odpowiedzialności nie jest celowe albo jest znacznie utrudnione, ze względu na możliwość zaistnienia niebezpieczeństwa dokonania nieprawidłowych ustaleń w płaszczyźnie odpowiedzialności karnej sprawcy czynu zabronionego. $\mathrm{W}$ aspekcie materialnoprawnym przedawnienie jest okolicznością uchylającą karalność, natomiast skutkiem procesowym przedawnienia jest zakaz wszczynania postępowania oraz nakaz umorzenia postępowania wszczętego w sprawie o przestępstwo, którego karalność ustała (art. $17 \S 1$ pkt 6 k.p.k.) ${ }^{22}$.

Art. $101 \S 1$ k.k. różnicuje okresy przedawnienia karalności w zależności od wagi przestępstwa. Najdłuższy (30-letni) jest okres przedawnienia karalności zbrodni zabójstwa, natomiast w odniesieniu do innych zbrodni okres ten wynosi lat 20. W przypadku występków okresy przedawnienia są zróżnicowane z uwzględnieniem kryterium grożącej kary. Okres przedawnienia karalności występków zagrożonych karą pozbawienia wolności przekraczającą 5 lat wynosi 15 lat, zaś występków zagrożonych karą pozbawienia wolności przekraczającą 3 lata wynosi 10 lat. W przypadku występków zagrożonych karą pozbawienia wolności do 3 lat oraz występków zagrożonych karami ograniczenia wolności lub grzywny okres przedawnienia karalności wynosi 5 lat.

W oparciu o przepis art. 102 k.k. ww. okresy przedawnienia ulegają przedłużeniu, jeżeli w trakcie ich trwania wszczęto postępowanie przeciwko osobie. Okres karalności zbrodni i występków zagrożonych karą pozbawienia wolności przekraczającą 3 lata wydłuża się odpowiednio o 10 lat, pozostałych występków - o 5 lat.

Niezależnie od tego w przypadku przestępstw przeciwko wolności seksualnej i obyczajności popełnionych na szkodę małoletnich, zgodnie z obowiązującym art. $104 \S 4$ k.k., przedawnienie nie może nastąpić przed upływem 5 lat od ukończenia przez pokrzywdzonego osiemnastu lat ${ }^{23}$. W przypadku kwalifikowanego typu zgwałcenia, gdy czyn dotyczy osoby małoletniej poniżej 15 lat (art. 197 § 3 k.k.), co stanowi zbrodnię, zagrożoną karą pozbawienia wolności na czas nie krótszy od 3 lat, okres przedawnienia jej karalności, zgodnie z art. $101 \S 1$ pkt 2 k.k., wynosi 20 lat. Trzeba przypomnieć, że wszczęcie w tym okresie postępowania przeciwko osobie spowoduje jego wydłużenie o 10 lat (art. 102 k.k.). W świetle tych przepisów przedawnienie karalności przestępstwa popełnionego na szkodę dziecka nastąpi

22 Szerzej na temat przedawnienia zob. P. Hofmański, S. Zabłocki, Przedawnienie, (w:) Elementy metodyki pracy sędziego w sprawach karnych, Zakamycze 2006, LEX nr 57992 oraz dostępne komentarze do Kodeksu karnego, np. A. Marek, Komentarz do art. 101 kk., (w:) A. Marek (red.), Kodeks karny. Komentarz, LEX 2010 nr 59783 czy też M. Mozgawa, Komentarz do art. 101 Kodeksu karnego, (w:) M. Mozgawa (red.). Kodeks karny. Komentarz, LEX 2013, nr 140895. Zob. także J. Konieczny, W kwestii przedawnienia karalności - art. 101 § 4 k.k., „Palestra” 2011, nr 9-10, s. 92.

Zmiany uchwalone ustawą z 24 lutego 2014 r. wejdą w życie 30 dni od dnia ogłoszenia ustawy. 
nie wcześniej, niż gdy pokrzywdzony będzie miał lat 30 (postępowanie przeciwko sprawcy nie zostało wszczęte) lub 40 (w przypadku wszczęcia postępowania).

Art. 105 k.k. w obowiązującym w dniu pisania artykułu brzmieniu wyłącza możliwość przedawnienia zarówno karalności, jak i wykonania kary w stosunku do wymienionych $\mathrm{w}$ nim przestępstw. Zgodnie $\mathrm{z}$ tym przepisem nie ulegają przedawnieniu zbrodnie przeciwko ludzkości i pokojowi oraz przestępstwa wojenne, a także niektóre umyślne przestępstwa popełnione przez funkcjonariusza publicznego w związku z pełnieniem obowiązków służbowych.

Jak wynika z przytoczonych przepisów rozdziału XI k.k., w prawie karnym zasadą jest przedawnianie się karalności nawet najbardziej poważnych przestępstw, do których należy np. zbrodnia zabójstwa, z wyjątkami od tej zasady określonymi w art. 105 k.k. Trzeba zatem postawić pytanie, jak należy ocenić przedłożone propozycje oraz ostatecznie uchwaloną ustawę w zakresie wydłużenia okresu przedawnienia $\mathrm{w}$ art. $101 \S 4$ k.k. w odniesieniu do wybranych czynów przeciwko nieletnim, a w szczególności - czy dojdzie do istotnej zmiany w tym zakresie.

Zanim przeanalizowane zostaną zobowiązania wynikające z prawa UE można zadać pytanie, czy w ogóle istnieją merytoryczne przesłanki uzasadniające wydłużenie okresu przedawnienia $\mathrm{w}$ stosunku do obowiązującego stanu prawnego, zwłaszcza, że będą one warunkowały zgodność z rozwiązaniami przyjętymi w dyrektywie. $\mathrm{Na}$ ten temat wypowiedziano się $\mathrm{w}$ trakcie prac nad projektami, a zatem można przytoczyć te poglądy.

W opinii z 16 października 2013 r. ${ }^{24}$ Sąd Najwyższy stwierdził, że „,brak jest niestety w uzasadnieniu danych empirycznych, w tym kryminologicznych, przemawiających za proponowanym rozwiązaniem" ${ }^{25}$. Sąd Najwyższy przedstawił argumenty przemawiające zarówno „za”, jak i „przeciw” proponowanej regulacji. Za zachowaniem obowiązujących dotychczas rozwiązań przemawia teza, że znaczny upływ czasu powoduje zniekształcenie lub utratę dowodów i w efekcie powoduje nietrafną reakcję karną, potęgując tym samym możliwość wystąpienia pomyłki sądowej. Nie da się jednak jednoznacznie stwierdzić, że wydłużenie okresu do 10 lat na pewno takie problemy dowodowe spowoduje. Za proponowanym rozwiązaniem wydłużenia okresu przedawnienia (ostatecznie uchwalonym), zdaniem Sądu Najwyższego przemawia fakt, że obecnie obowiązujący pięcioletni okres przypada na czas, w którym

24 Opinia BSA II-021-368/13: http://orka.sejm.gov.pl/Druki7ka.nsf/0/ABC6CC336FEFD059C1257C0F00443140/\%24File/1827-003.pdf

Również dr Piotr Kluz, opiniujący projekt rządowy stwierdza w opinii z 10 lutego 2014 r., że projektodawca nie wykazał, dlaczego na chwilę obecną konieczne stało się podwyższenie okresu przedawnienia z 5 lat na lat 10 od ukończenia przez małoletniego 18 lat, innymi słowy dlaczego obecnie obowiązujący okres jest niewystarczający dla skutecznego, samodzielnego wszczęcia postępowania po uzyskaniu przez pokrzywdzonego pełnoletniości. Z kolei dr hab. A. Sakowicz w swojej opinii z 4 lutego 2014 r. stwierdza, że obowiązujący przepis art. 101 § 4 k.k. zapewnia pokrzywdzonemu małoletniemu czas wystarczający dla skutecznego oraz samodzielnego wszczęcia postępowania karnego po uzyskaniu przez niego pełnoletności. Czyni on także zadość zobowiązaniom międzynarodowym. Projektodawca nie wskazuje argumentów przemawiających za powyższą zmianą, które osadzone są w praktyce organów ścigania i wymiaru sprawiedliwości. Obie opinie dostępne są na stronie http://orka.sejm. gov.pl/rexdomk7.nsf/Opdodr?OpenPage\&nr=2016 (dostęp 28 lutego 2014 r.). 
dorosły pokrzywdzony nadal jest utrzymywany przez domniemanych sprawców, a tym samym psychicznie i fizycznie od nich zależny. Może to utrudniać decyzję o ujawnieniu przestępstwa. Sąd Najwyższy nie wykluczył zatem zasadniczo sensu proponowanych rozwiązań, ale podkreślił brak dowodów na potwierdzenie, że faktycznie obowiązujący okres przedawnienia jest zbyt krótki.

Z kolei w stanowisku rządu do druku nr 1827 czytamy, że należy zgodzić się, iż przewidziane wydłużenie okresu przedawnienia karalności do 5 lat po ukończeniu przez pokrzywdzonego małoletniego 18 lat może w niektórych przypadkach być niewystarczające. Jakkolwiek osoby w wieku 23 lat posiadają bowiem pełną zdolność do czynności prawnych, to nierzadko nie osiągnęły one jeszcze emocjonalnej i ekonomicznej samodzielności w stopniu, który umożliwiłby im efektywną ochronę własnych praw. Nie bez znaczenia pozostaje przy tym traumatyzujący dla ofiar charakter przestępstw seksualnych oraz ryzyko społecznej dezaprobaty dla dochodzenia przez nie swoich praw. Dodatkowe utrudnienie w podjęciu decyzji o ujawnieniu przestępstwa stanowi fakt, iż sprawcami przestępstw o charakterze seksualnym, których ofiarami są małoletni, są często osoby z bliskiego otoczenia małoletniego. Opóźnienie momentu przekazania właściwym organom informacji o popełnionym przestępstwie może ponadto powodować trudności w zakończeniu przewidzianych prawem czynności przed upływem okresu przedawnienia karalności. Podstawowy cel zaproponowanych zmian zasługuje na poparcie. Wydłużenie z 5 do 10 lat okresu, w którym po ukończeniu przez małoletniego 18 lat nie może nastąpić przedawnienie karalności przestępstw o charakterze seksualnym, którymi został on pokrzywdzony, jest zasadne oraz zgodne z kierunkiem zmian proponowanych we wskazanym powyżej projekcie rządowym.

Z kolei Prokuratura Generalna w opinii z 5 grudnia 2013 r. ${ }^{26}$ zwraca uwagę, że widoczne jest dążenie do optymalizacji okresu, w którym pełnoletni już pokrzywdzony może inicjować postępowanie karne. Okres ten powinien być nie tylko wystarczający dla uzewnętrznienia sfery motywacyjnej, ale i proporcjonalny do wagi przestępstwa.

\section{Ocena zgodności z prawem UE}

Stwierdzając zatem, że nie przedstawiono żadnych argumentów, które osadzone byłyby w praktyce wymiaru sprawiedliwości i które przemawiałyby za wydłużeniem okresu przedawnienia, należy zastanowić się, jak do tej kwestii odnoszą się przepisy prawa wtórnego UE.

Jak już zostało wskazane wyżej, w prawie UE kwestia przedawnienia karalności przestępstw związanych z niegodziwym traktowaniem w celach seksualnych 
i wykorzystywaniem seksualnym dzieci, pornografią dziecięcą oraz nagabywaniem dzieci do celów seksualnych jest przedmiotem dyrektywy 2011/93/UE.

Zgodnie z art. 15 ust. 2 dyrektywy, państwa członkowskie podejmują środki niezbędne do umożliwienia ścigania wszelkich przestępstw, o których mowa w art. 3, art. 4 ust. 2, 3, 5, 6 i 7 oraz wszelkich poważnych przestępstw, o których mowa w art. 5 ust. 6, w związku z którymi wykorzystano pornografię dziecięcą, o której mowa w art. 2 lit. c ppkt i oraz ii, przez wystarczający i proporcjonalny do wagi danego przestępstwa okres od momentu osiągnięcia przez pokrzywdzonego pełnoletniości.

Oceniając zatem przedstawione propozycje pod kątem ich zgodności z prawem UE należy zbadać, czy proponowany okres spełnia te dwa kryteria. Rozpoczynając od propozycji wydłużenia okresu do 10 lub 12 lat (od momentu ukończenia przez pokrzywdzonego 18 lat), w odniesieniu do przestępstw wymienionych w art. 101 $\S 4$ k.k. należy stwierdzić, że nie wydaje się, by można było uznać, że proponowany okres nie jest wystarczający czy proporcjonalny. Dyrektywa nie precyzuje, o jaki konkretnie okres chodzi i pozostawia to uznaniu prawodawcy krajowego, który powinien w tym względzie kierować się własną argumentacją, popartą przesłankami wynikającymi z praktyki wymiaru sprawiedliwości.

Trzeba zatem przypomnieć, że jak wynika z wszystkich przedłożonych projektów, zarówno posłowie różnych ugrupowań, jak i rząd stanęli na stanowisku, że obowiązujący termin przedawnienia nie jest wystarczający. Co prawda, jak wskazano wyżej, nie przedstawiono żadnych uzasadnien, które wynikałyby z przeprowadzonych badań ani wyników dostępnych statystyk i innych argumentów z praktyki, to jednak wszyscy zgodnie wskazują, że proponowane zmiany w k.k. mają na celu ochronę interesów pokrzywdzonych, a zatem realizują cel wskazany w dyrektywie. Oceniając zgodność projektów z prawem UE należałoby zatem przyjąć takie twierdzenie projektodawców, że obowiązujący okres 5 lat od ukończenia przez pokrzywdzonego 18 lat może być w praktyce okresem zbyt krótkim. Nie jest zadaniem prawa UE polemizowanie z takimi twierdzeniami, lecz raczej przyjęcie argumentacji krajowej. Hipotetycznie jednak w sytuacji, w której prawodawca krajowy próbowałby ten okres skrócić, uzasadniając, że okres np. 3 lat jest wystarczający, dla stwierdzenia niezgodności z prawem UE również konieczne byłoby przedstawienie argumentów przemawiających za poglądem odmiennym. Zatem skoro wnioskodawcy wskazują, że „choć wiek 23 lat oznacza pełną zdolność do czynności prawnych, często wiąże się z brakiem dorosłości i samodzielności. W praktyce oznacza to niemożność przeciwstawienia się sprawcy i ochrony własnych podstawowych praw" i ustawodawca uznaje, że celem proponowanego wydłużenia okresu przedawnienia jest zapewnienie pokrzywdzonemu małoletniemu czasu wystarczającego dla skutecznego, samodzielnego wszczęcia postępowania po uzyskaniu pełnoletniości, to przyjąć należy, że tym samym wymóg proporcjonalności i adekwatności proponowanego rozwiąza- 
nia, wymagany w art. 15 ust. 2 dyrektywy w sprawie seksualnego wykorzystywania dzieci oraz art. 9 ust. 2 dyrektywy w sprawie handlu ludźmi, jest spełniony.

W tym zakresie zatem projekty, które przewidują wydłużenie okresu przedawnienia do 10 lub do 12 lat, są zgodne z prawem Unii Europejskiej i realizują założenia art. 15 ust. 2 dyrektywy. Aby jednak stwierdzić, czy przedłożone projekty wykonują (implementują) dyrektywę na obecnym etapie stanowienia prawa, konieczne stałoby się wykazanie w oparciu o praktykę, że nadal obowiązujący okres 5 lat jest okresem niewystarczającym, a to wymagałoby przedstawienia dalej idących argumentów niż tezy wskazane w uzasadnieniach do projektów. W chwili obecnej nie ma przesłanek, które pozwoliłyby stwierdzić, że obowiązujący okres jest niewystarczający i w efekcie sprzeczny z dyrektywami. Przyjęta ustawa, a wcześniej projekty, nie mogły zatem zostać uznane za projekty wykonujące prawo UE, o ile nie zostałoby dowiedzione, że obowiązujące rozwiązanie jest sprzeczne z prawem UE.

Odnosząc się natomiast do propozycji, w której przestępstwa te nie miałyby w ogóle ulec przedawnieniu, należy ponownie przypomnieć treść art. 15 ust. 2 dyrektywy, który nie precyzuje, o jaki konkretnie okres chodzi. Zakłada się zatem, że zostanie wyznaczony pewien okres, podlegający ocenie w szczególności pod kątem jego ,,proporcjonalności” i ,wystarczalności” w odniesieniu do wagi czynu. Powstaje zatem kolejne pytanie, czy niewyznaczenie żadnego okresu przedawnienia i uznanie, że przestępstwa te nie podlegają przedawnieniu, jest zgodne z przepisem dyrektywy.

Aby odpowiedzieć na to pytanie, należy odnieść się do zakresu kompetencji Unii Europejskiej w odniesieniu do krajowego prawa karnego. Trzeba zatem stwierdzić wyraźnie, że współpraca wymiarów sprawiedliwości państw członkowskich w sprawach karnych, określona w art. 82 i n. Traktatu o funkcjonowaniu Unii Europejskiej (TFUE), jest elementem tzw. przestrzeni wolności, bezpieczeństwa i sprawiedliwości UE, a zatem jest elementem tzw. kompetencji dzielonych (art. 4 ust. 2 TFUE). Zgodnie z art. 2 ust. 2 TFUE, w takim przypadku Unia i państwa członkowskie mogą stanowić prawo i przyjmować akty prawnie wiążące w tej dziedzinie. Państwa członkowskie wykonują swoją kompetencję w zakresie, w jakim Unia nie wykonała swojej kompetencji. Trzeba również wskazać na art. 83 ust. 1 TFUE, który był podstawą do przyjęcia ww. dyrektywy i w którym wyraźnie wskazano, że Parlament Europejski i Rada mogą ustanowić normy minimalne odnoszące się do określania przestępstw oraz kar w dziedzinach szczególnie poważnej przestępczości o wymiarze transgranicznym (w tym w zakresie seksualnego wykorzystania dzieci). Traktat zatem wyraźnie wskazuje, że kompetencje Unii Europejskiej nie wykraczają poza określenie pewnego standardu minimalnego, czyli poziomu wyjściowego, który następnie może podlegać dalszym regulacjom krajowym. Minimalny charakter regulacji dyrektywy potwierdza również motyw 26 preambuły do niej, gdzie wyraźnie stwierdza się, że wystarczający okres, w ciągu którego można ścigać przestępstwo, należy określić zgodnie z prawem krajowym. Oznacza to, że art. 15 ust. 2 
dyrektywy należy rozumieć w ten sposób, że jego celem jest, by państwa członkowskie umożliwiły ściganie wymienionych w nim przestępstw w okresie, który nie będzie okresem zbyt krótkim i umożliwi pokrzywdzonemu dochodzenie swoich praw. Stwierdzenie, że czyn nie podlega w ogóle przedawnieniu realizuje te założenia, bo umożliwia ściganie przestępstw w każdym czasie.

Artykuł 105 k.k., do którego projektodawcy proponowali dodanie omawianego $\S 3$, wprowadza wyjątek od ogólnej zasady, zgodnie z którą zarówno karalność przestępstwa, jak i możliwość wykonania orzeczonej za nie kary ustaje z upływem pewnego czasu. Należy zauważyć, że na mocy obecnie obowiązującego art. 105 k.k., nie przedawniają się: zbrodnie przeciwko pokojowi, ludzkości, przestępstwa wojenne, a także umyślne przestępstwa zabójstwa, ciężkiego uszkodzenia ciała, ciężkiego uszczerbku na zdrowiu lub pozbawienia wolności łączonego ze szczególnym udręczeniem, popełnionego przez funkcjonariusza publicznego w związku z pełnieniem obowiązków służbowych. Do tego katalogu projektodawcy proponują dodać przestępstwa określone w ww. artykułach.

Uzasadnieniem tego wyjątku jest szczególny ciężar gatunkowy niektórych przestępstw, który powoduje, że argumenty przemawiające za przedawnieniem, takie jak zacieranie się poczucia krzywdy czy dezaktualizacja potrzeby karania - tracą rację bytu ${ }^{27}$. Należy podkreślić, że przedawnienie karalności (analogicznie przedawnienie wykonania kary) nie jest uprawnieniem sprawcy przestępstwa, który może oczekiwać, że po upływie określonego czasu popełnione przez niego przestępstwo nie będzie podlegało karze (orzeczona kara nie zostanie wykonana). Zakres przestępstw, których karalność ulega przedawnieniu lub za które wykonanie orzeczonej kary ulega przedawnieniu, jest domeną prawa karnego ${ }^{28}$.

Zmiany zaproponowane w projekcie ustawy, o ile zostałyby przyjęte, oznaczałyby, że wolą polskiego ustawodawcy jest to, by wymienione czyny nie podlegały przedawnieniu. Celem tej propozycji jest zapewnienie pokrzywdzonemu małoletniemu czasu wystarczającego dla skutecznego, samodzielnego wszczęcia postępowania po uzyskaniu pełnoletniości. W uzasadnieniu do projektu wnioskodawcy wskazują, że zmiany są konieczne „dla zapewnienia możliwości skutecznego egzekwowania odpowiedzialności karnej sprawców przestępstw o charakterze seksualnym (...). Z uwagi na charakter tych przestępstw, ich indywidualność, emocjonalność oraz możliwość przez pokrzywdzonego dochodzenia swoich praw, właściwym jest zakwalifikowanie przez ustawodawcę tych czynów zabronionych do katalogu przestępstw z art. 105 Kodeksu karnego, a więc niepodlegających przedawnieniu".

Należy zatem stwierdzić, że przedłożony projekt również realizował cel, jaki jest wskazany w art. 15 ust. 2 dyrektywy w ten sposób, że umożliwia ściganie sprawKomentarz, WKP 2012, LEX nr 125625. 
Przedawnienie karalności przestępstw seksualnych w kontekście prawa Unii Europejskiej...

ców przestępstw wymienionych w dodawanym art. $105 \S 3$ k.k. w każdym czasie. Tym samym nie mógł być uznany za sprzeczny z art. 15 ust. 2 dyrektywy.

\section{Podsumowanie}

Niniejsza analiza dotyczy przedstawionych ostatnio kilku propozycji związanych $\mathrm{z}$ wydłużeniem okresu przedawnienia $\mathrm{w}$ odniesieniu do przestępstw o charakterze seksualnym popełnionych wobec małoletnich. Chociaż ostatecznie polski ustawodawca wybrał jeden z tych wariantów i ustawa została uchwalona, to jednak analiza pozostałych przypadków może przyczynić się do dalszej dyskusji na temat harmonizacji prawa karnego państw członkowskich UE i zakresu obowiązków nałożonych na państwa.

Ocena zgodności z prawem UE omówionych propozycji wymagałaby przedstawienia uzasadnienia opartego o praktykę wymiaru sprawiedliwości wskazującego, że faktycznie wydłużenie okresu przedawnienia jest potrzebne dla ochrony pokrzywdzonych. Dyrektywa wymaga, by okres ten był proporcjonalny i wystarczający dla dochodzenia swoich praw przez pokrzywdzonego. Pomimo że polski ustawodawca nie przedstawił argumentów opartych na statystykach, procedurach czy innych przykładach, to jednak nie można z góry założyć, że proponowany czy ostatecznie uchwalony okres nie spełnia tych wymogów. Tym samym żadna z przedstawionych propozycji nie jest sprzeczna z prawem UE. Nie można jednak uznać, że projekty implementują dyrektywę, bo to zakładałoby, że obowiązujący dotychczas okres 5 lat jest niewystarczający - a na to również nie przedstawiono żadnych dowodów.

W literaturze wyrażono pogląd, że w d. III filarze UE oraz na podstawie aktów, których podstawą prawną jest art. 83 TFUE nie przyjęto jeszcze aktów prawnych, które umożliwiałyby harmonizację okresów przedawnienia przestępstww ${ }^{29}$. Pogląd ten jest nadal aktualny - przyjęte dotychczas akty prawne, takie jak omówiona dyrektywa 2011/93/UE, nie zmierzają do harmonizacji okresów przedawnienia, pozostawiając te kwestie regulacji wewnętrznej państw członkowskich. 29 C.-F. Stuckenberg, Allgemeiner Teils eines Europäischen Strafrechts, (w:) M. Böse (red.), Europäisches Stra-
frecht mit polizeilicher Zusammenarbeit, Nomos Baden-Baden 2013, § 10, RN 60, s. 404. 


\section{STATUTE OF LIMITATIONS FOR SEXUAL CRIMES IN THE CONTEXT OF EUROPEAN UNION LAW}

The Author analyses several proposals presented in recent months to the Marshall of the Sejm in which the statute of limitations of sexual offences in cases involving juvenile victims is discussed. The study raises this general problem in the context of EU law, especially in the light of Directive 2011/93/EU of the European Parliament and of the Council of 13 December 2011, on combating the sexual abuse and sexual exploitation of children and child pornography. Although the Polish legislator has already chosen one of these options and the law adopted, analysis of the remaining cases can lead to further discussions on the harmonization of criminal law of the Member States of the EU and the scope of the obligations imposed on the state. Assessment of compliance with EU law of all proposals would require a justification based on the practice of justice indicating that actually extending the statute of limitations period is necessary for the protection of victims. Although the Polish legislator did not provide arguments based on statistics, procedures or other such examples, it cannot be assumed that the proposed and finally adopted law is not compatible with these requirements. Thus, none of the proposals are contrary to EU law.

Keywords: statute of limitations, sexual crimes, sexual exploitation of children 